\title{
Assessment of metal and metalloid contamination in soils trough compositional data: the old Mortórios uranium mine area, central Portugal
}

\author{
A. M. R. Neiva - M. T. D. Albuquerque $\cdot$ I. M. H. R. Antunes $(\mathbb{D} \cdot$ \\ P. C. S. Carvalho - A. C. T. Santos $\cdot$ C. Boente $\cdot$ P. P. Cunha - S. B. A. Henriques \\ R. L. Pato
}

Received: 27 January 2019/Accepted: 5 June 2019

(C) Springer Nature B.V. 2019

\begin{abstract}
Soils from the old Mortórios uranium mine area were studied to look for contamination, as they are close to two villages, up to $3 \mathrm{~km}$ away, and used for agriculture. They are mainly contaminated in $\mathrm{U}$ and As and constitute an ecological threat. This study attempts to outline the degree to which soils have been affected by the old mining activities through the computation of significant hot clusters, Traditional geostatistical approaches commonly use raw data (concentrations) accepting that the analyzed elements represent the soil's entirety. However, in geochemical studies these elements are just a fraction of the total soil composition. Thus, considering compositional
\end{abstract}

A. M. R. Neiva: This paper is dedicated to the memory of our friend, Prof. Ana Neiva.

A. M. R. Neiva · A. C. T. Santos

GeoBioTec, Department of Geosciences, University of

Aveiro, Aveiro, Portugal

A. M. R. Neiva - A. C. T. Santos · P. P. Cunha

Department of Earth Sciences, University of Coimbra,

Coimbra, Portugal

M. T. D. Albuquerque

Qualidade de Vida e o Mundo Rural (QRural) Research

Center, Instituto Politécnico de Castelo Branco,

Castelo Branco, Portugal

I. M. H. R. Antunes ( $\square)$

ICT, University of Minho, Braga, Portugal

e-mail: imantunes@dct.uminho.pt data is pivotal. The spatial characterization, considering raw and compositional data together, allowed a broad discussion about not only the concentrations' spatial distribution, but also a better understanding on the possibility of trends of "relative enrichment" and, furthermore an insight in $U$ and As fate. The highest proportions (compositional data) on $\mathrm{U}$ (up to $33 \%$ ), As (up to $35 \%$ ) and Th (up to 13\%) are reached in the south-southeast segment. However, the highest concentrations (raw data) occur in north and northwest of the studied area, pointing out to a "relative enrichment" toward the south-southeast zone. The Mondego Sul area is mainly contaminated in $\mathrm{U}$ and As, but also in $\mathrm{Co}, \mathrm{Cu}, \mathrm{Pb}$ and $\mathrm{Sb}$. The Mortórios area is less contaminated than the Mondego Sul area.

\section{P. C. S. Carvalho · P. P. Cunha}

MARE - Marine and Environmental Science Centre,

University of Coimbra, Coimbra, Portugal

C. Boente

INDUROT and Environmental Technology,

Biotechnology, and Geochemistry Group, Universidad de

Oviedo, Campus de Mieres, 33600 Mieres, Asturias, Spain

S. B. A. Henriques

Laboratório Nacional de Energia e Geologia (LNEG), Alfragide, Portugal

R. L. Pato

Research Centre for Natural Resources, Environment and Society, Agrarian School, Polytechnic Institute of Coimbra, Coimbra, Portugal 


\section{Graphic abstract}



Keywords Raw data $\cdot$ Compositional data $\cdot$ Spatial analysis $\cdot$ Health risks $\cdot$ Open pit lake $\cdot$ Dumps

\section{Introduction}

The assessment of soil contamination using trace elements is a key process in environmental assessment and subsequent management. The type of soil and geological setting determine the mobility of uranium and other metals in soil. The concentration of pollutant species in the soil varies according to the source of contamination-natural and anthropogenic-such as mining activities (e.g., Neiva et al. 2016; Albuquerque et al. 2017; Antunes et al. 2018; Boente et al. 2018a; $\mathrm{Fu}$ et al. 2018; González-Fernández et al. 2018; Selvakumar et al. 2018).

Contaminants leaching from open pits and dumps going toward streams, sediments and soils are causing a significant contamination, which affects water, plants, animals and people. Contaminant dispersion and enrichment areas will allow a contamination degree assessment that have been affected by previous or existing mining activities. At contaminated sites, uranium can enter in the food chain through soil- plant-animal interactions, surface water and groundwater (Neiva et al. 2016). The contaminant interaction with soil type will change with alteration, adsorption and dispersion processes (Selvakumar et al. 2018).

Risk maps are a very powerful tool to support policy-making in environmental risk assessment framework allowing a spatial pattern visualization of contaminant distribution, exposure and its effects, and vulnerability assessment (Lahr and Kooistra 2010; Li et al. 2015). It is possible to determine contaminant distribution and identify the more contaminated or enriched areas (hotspots). Geochemical data are typically reported as compositions (raw data), in the form of proportions subject to a constant sum (e.g., $100 \%$, $1 \mathrm{ppm}$ ), which implies that such data are "closed" and for an individual component composition without all environmental contributions (Buccianti and Grunsky 2014). Raw data treatment methodologies must be able to capture our perception of the natural scale of the data and a better understanding of environmental processes. However, a spatial distribution of proportions defined to a specific batch of elements (compositional data) will also allow the definition of contamination trends in an area.

In the present research, the metals and metalloids total concentration in the studied soils of the 
abandoned U-mine area from Mortórios (Central Portugal) were used to interpret the contamination outbreaks and therefore locate the main sources of in situ enrichment (hotspots) and the distribution of contamination patterns. This study will promote the identification of contaminated areas and consequent availability assessment and site specific-risk environmental assessment.

\section{Analytical methods and data modeling}

Study area

The old Mortórios uranium mine area is located between the Marialva and Carvalhal villages, in the Guarda county, central Portugal (Fig. 1a, b) and in the Central Iberian Zone of the Iberian Massif (e.g., Farias et al. 1987). It is one of the many mines from the uranium-bearing Beiras area. This mine consists of basic rock dykes of 0.1 to $14 \mathrm{~m}$ thick containing torbernite and autunite which cut the syn-D3 coarsegrained porphyritic granite. These dykes are associated with older small quartz veins containing wolframite, pyrrhotite, arsenopyrite, pyrite and chalcopyrite (JEN 1959). This uranium-bearing area

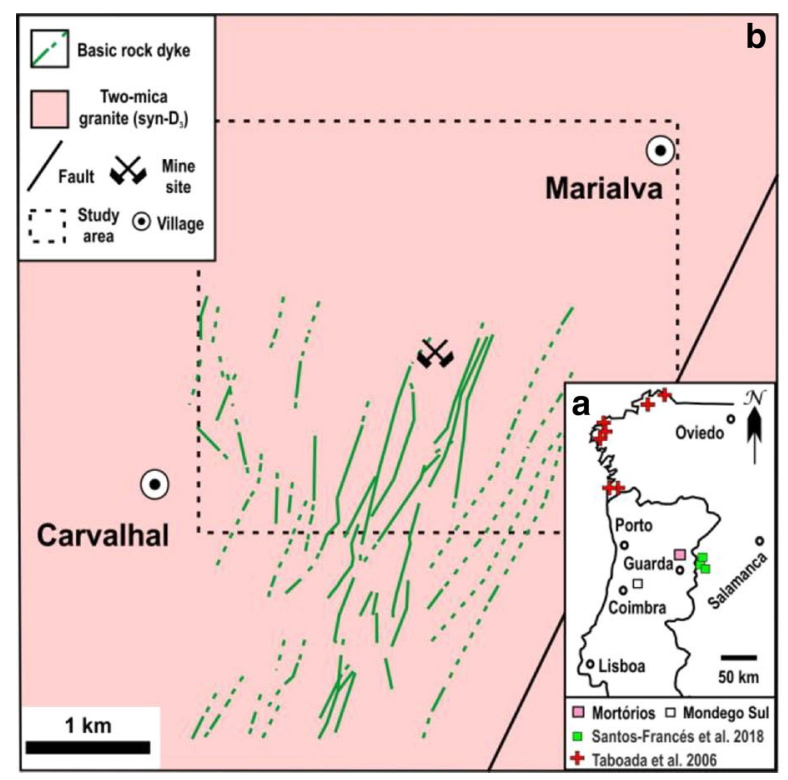

Fig. 1 Mortórios uranium mine area and collected soil samples. a Location of the study area and the Mondego Sul area in the map of Portugal. Locations of three areas for the baseline of $U$ and of seven profile areas for the baseline of Th in was $470 \mathrm{~m}$ long. It produced about 4.5 tonnes of uranium every year from 1982 to 1988 (Fortes et al. 2001).

The old Mortórios uranium mine area has a pit lake containing $126,800 \mathrm{~m}^{3}$ of water and eight dumps (Fig. 1c). The total volume of dump materials is $135,732 \mathrm{~m}^{3}$ (Quintela 2015). The dumps contain tailings, waste rocks and rejected materials. Some dumps are located near the road and were used to get sand and materials for buildings and roads (Madruga et al. 2010). The area has mainly herbaceous species, but there are also Pinus. Small agricultural areas occur around the old uranium mine. They contain potatoes crops, vineyards and pastures.

\section{Analytical methods}

Overlaying the survey area of the old Mortórios uranium mine area, a regular grid of $500 \times 500 \mathrm{~m}$ was created for point sampling. Within each square, two twin samples were generally picked up at a length of about $50 \mathrm{~m}$. The total of 50 samples were collected in an area about $4 \mathrm{~km}^{2}$ on the 30th of June 2014 (Fig. 1c).

The samples were collected at a depth of 20-30 cm and were transported in polyethylene bags to the

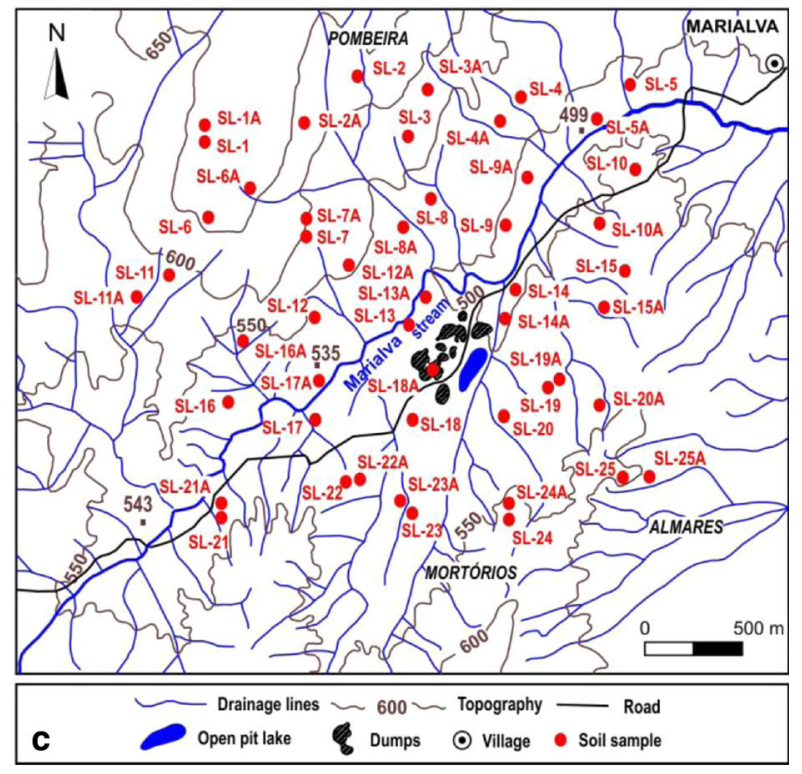

the partial Spanish map; b Geological map and delimitation of the Mortórios area (Adapted from Oliveira et al. 1992; JEN 1959); c Location of the open pit lake, dumps and soil samples in the topographic map (adapted from IGE 1994) 
laboratory. They were dried at $40{ }^{\circ} \mathrm{C}$, disaggregated with a rubber hammer and sieved through a $2-\mathrm{mm}$ nylon sieve. The $\mathrm{pH}$ was measured in a solid-water suspension with a liquid/solid ratio of 2.5 (British standard 1995a). The electrical conductivity (EC) was measured in a solid-water suspension with a liquid/solid ratio of 2.5 (British standard 1995b).

Soil samples $<250 \mu \mathrm{m}$ were digested with aqua regia $\left(3: 1 \mathrm{HCl}-\mathrm{HNO}_{3}\right)$, filtered through a $2 \mu \mathrm{m}$ filter and analyzed by ICP-OES using a Horiba Jobin-Yvon JV20002 spectrometer with a monochromator to determine several metals and metalloids total contents. Duplicate blanks and a laboratory standard were included in each batch of twenty-six samples. An internal reference soil, prepared with aqua regia and validated using the certified sewage sludge amended soil BCR-143R, was used (Table 1). Detection limits were obtained using a blank signal and dispersion estimated by sampling signal in the $0.5 \mathrm{~s}$ interval following the ICP-OES (User manual 2001). The conversion of the detection limit from $\mathrm{mg} / \mathrm{L}$ to $\mathrm{mg} / \mathrm{kg}$ was estimated using the following equation (DL $\mathrm{mg} /$ $\mathrm{kg})=(X * 0.1) / \mathrm{m}$, where $X$ is the $\mathrm{DL}$ at $\mathrm{mg} / \mathrm{L}$ given by the ICP-OES and $\mathrm{m}$ is the average of the heavy masses of the samples in $\mathrm{kg}$. The results were obtained in the Department of Earth Sciences of the University of Coimbra and were accepted if they were lower than those shown in Table 1.

The textural characteristics were obtained in four soil samples from north and eight samples from south of the open pit lake and dumps. A Coulter laser granulometer ( $2 \mathrm{~mm}-0.04 \mu \mathrm{m}$; precision up to $5 \%$ ) was used to get the grain distribution of the fraction $<2 \mathrm{~mm}$ of the samples by laser diffraction analysis. A Philips PW3710 X-ray diffractometer, with a $\mathrm{Cu}$ tube at $40 \mathrm{kV}$ and $20 \mathrm{nA}$, was used for X-ray diffraction to enable the mineralogical identifications of clay minerals in the $<2 \mu \mathrm{m}$ fraction in oriented samples before and after treatments with ethylene glycol and heating up to $550{ }^{\circ} \mathrm{C}$. All determinations were carried out in the Department of Earth Sciences, University of Coimbra, Portugal.

Organic matter $(\mathrm{OM})$ and cation exchange capacity (CEC) were determined in twelve soil samples. The organic carbon (OC) was determined by dry combustion with an elemental analyzer (SC 144DR, LECO). The samples were heated at $590{ }^{\circ} \mathrm{C}$, oxidized to $\mathrm{CO}_{2}$ and quantified in the infra-red gas cell. To quantify the organic matter, the van Bemmelen factor of 1.724 (Tabatabai 1996) was used $(\%$ OM $=\%$ OC $\times$ $1.724)$, with an accuracy of $1 \%$. The exchange of cations $(\mathrm{cmol} / \mathrm{kg})$ was carried out with $1 \mathrm{M}$ ammonium acetate pH 7 (1/10) extraction (Thomas 1982) and determined by atomic absorption spectrometry (PinAAcle 900T, PerkinElmer). The CEC was calculated at $\mathrm{pH} 7.0$ from the individual cation values $(\mathrm{CEC}=$ Sum of exchangeable bases + exchange acidity) with quantification of the exchange acidity by extraction with $1 \mathrm{~N}$ potassium chloride $(1 / 20)$ and titration with $\mathrm{NaOH}$ of a known title until $\mathrm{pH} 7.0$ (Chernov 1947; Nye et al. 1961), with an accuracy of $0.38 \%$. These determinations were carried out at the Agrarian School of Coimbra, in the Soil and Fertility Laboratory.

\section{Data modeling}

\section{Data transformation-geochemical data and the closure problem}

In geochemistry, compositional data respect to the transformation of each original raw concentration (i.e., $\mathrm{mg} / \mathrm{kg}$ ) into proportions of a considered whole (in the case at hands: As; $\mathrm{Co} ; \mathrm{Cr} ; \mathrm{Mn}$; Th; $\mathrm{U} ; \mathrm{Cu} ; \mathrm{Ni} ; \mathrm{Pb} ; \mathrm{Sr} ; \mathrm{W}$;

Table 1 Allowance of accuracy and precision for routine analysis

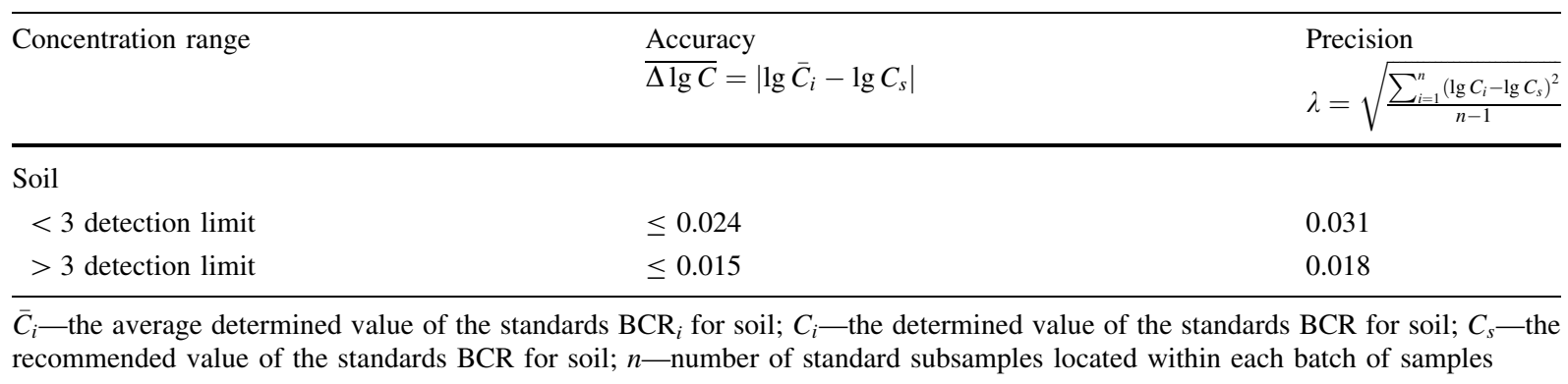


$\mathrm{Zn}$ ), whose elements must sum one-100\% (Pawlowsky-Glahn and Egozcue 2006). This topic has been much debated and referred in the literature as the closure problem (Filzmoser et al. 2009). In environmental science studies, it is in general accepted that the chosen analyzed elements correspond to the entirety of the soil, if a suitable number of those attributes is included in the survey (Campbell et al. 2009; Reimann et al. 2012). However, other authors work with what is called subcompositions which define a subset of parts of a composition (Pawlowsky-Glahn and Buccianti 2011). Subcompositions are accurate when the principles of compositional data are respected (Greenacre and Lewi 2009), including the subcompositional coherence principle (Aitchison 1986).

The log-ratio transform functions most used (alr; clr and ilr) have advantages but also disadvantages (Pawlowsky-Glahn and Buccianti 2011; Boente et al. $2018 b)$. The clr transformation is the most used in geochemical studies since the geometric mean is used as a normalizer parameter, and it was the chosen transformation for the purposes of the herein survey.

The equation of the centered log-ratio transformation (clr) was adjusted from (Aitchison 1986):

$\operatorname{clr}(x)=\ln \left(\frac{C_{j}}{\sqrt[D]{\prod_{j=1}^{D} C_{j}}}\right)$

where $C_{j}$ corresponds to the concentration of the contaminant $j$ and $D$ corresponds to the number of sections into which the composition is segmented, namely the number of considered contaminants.

The back-transformation equation is as follows:

$\overline{\operatorname{clr}}(x)=\frac{\mathrm{e}^{\operatorname{clr}(x)}}{\sum_{j=1}^{D} \mathrm{e}^{\operatorname{clr}(x)}}$

After this transformation, the represented data (clrtransformed data) may be considered as compositional data (proportions) and the sum of all the considered elements after back-transformation must be equal to 1 . The clr transformation and its back-transformation were performed using CoDaPack v2.02.21 software (http://www.composiotionaldata.com/codapack.php).

\section{Spatial modeling}

The spatial characterization of the chosen elements' distribution-U, As, Co and $\mathrm{Th}-$ was performed using ordinary kriging $(\mathrm{OK})$ aiming the definition of spatial distribution patterns and hotspots of $\mathrm{U}, \mathrm{As}$, Co and Th location, in the study area. For this purpose, the concentrations of the elements at study (raw data) were used, allowing to interpret the contamination outbreaks and therefore locate the main sources of natural in situ contributions. However, more than simply looking at the elements, concentrations distribution, it is keen to understand their fate. Thus, the development of a new approach aiming to examine the changes in their proportions along the survey area (compositional data) allowed to define trends of dissemination. The compositional dataset went after through a stochastic spatial modeling through "OK," and the computed spatial patterns used to tackle this issue (Boente et al. 2018b).

In synthesis, a two-step methodology was adopted as follows: (1) The selected attributes went through structural analysis, and experimental variograms were computed for both raw and compositional data and the best fitted theoretical models adjusted. The variogram is a vector function used to calculate the spatial variation structure of regionalized variables (Matheron 1963; Journel and Huijbregts 1978; Gringarten and Deutsch 2001); (2) spatial estimation through geostatistical interpolation (OK) allowed to predict spatial distribution patterns of the variables at hand for any arbitrary location (e.g., Albuquerque et al. 2017). The raw dataset was used to define concentrations spatial patterns as the compositional dataset was used for the definition of trends of dissemination and relative enrichment in $\mathrm{U}, \mathrm{As}, \mathrm{Co}$ and $\mathrm{Th}$.

To stress that the primary application of geostatistical methodologies is the estimation and mapping of environmental attributes. Kriging is the generalized name for an assemble of generalized least-squares regression algorithms. Ordinary kriging respects to local fluctuations of the mean, limiting the correspondent stationary to the local neighborhood (Goovaerts 1997). For the computation, the Space-Stat Software V. 4.0.18, BioMedware was used (Albuquerque et al. 2017).

\section{Results and discussion}

Geochemistry of soils

The textural characteristics, physical-chemical parameters and concentrations of metals and 
metalloids of soils from the old Mortórios uranium mine area are presented in Table 2. The sample 18A was collected close to the open pit lake.

The textural characteristics were determined in a selected number of samples (Table 2). In general, they are dominated by sandy gravels. They consist of granite, quartz, feldspars, muscovite, biotite and rarely contain shale. The clay $(<4 \mu \mathrm{m})$ content is very low $(0.06-0.35 \%)$. In the clay mineralogy, dominates the association vermiculite, smectite, and kaolinite. Smectite was found in five of the twelve studied samples. The fraction $<2 \mu \mathrm{m}$ presents kaolinite (9-38\%), smectite $(0-53 \%)$, vermiculite $(0.58 \%)$ and illite (21-66\%). The $\mathrm{pH}$ values are acidic 4.00-6.34, mainly due to the host two-mica granite influence. The EC values are low ranging between 1 and $84 \mu \mathrm{S} / \mathrm{cm}$, suggesting a low contamination. The highest EC value occurs at north of the open pit lake and dumps (Table 2).

The OM concentrations in soils range from 0.84 to $1.27 \%$ at south of the open pit lake and dumps and from 0.49 to $1.65 \%$ at north of the same sampling locations. Organic carbon is of great importance since it is a major uranium binding partner in soils (e.g., Gruan et al. 2000; Cumberland et al. 2016; Bone et al. 2017). The CEC presents $1.84-3.5 \mathrm{cmol}_{\mathrm{c}} \mathrm{kg}^{-1}$ at south of the open pit lake and dumps and 2.2-6.1 $\mathrm{cmol}_{\mathrm{c}} \mathrm{kg}^{-1}$ at north, revealing low CEC values in both cases.

The highest concentrations of metals $\mathrm{Fe}, \mathrm{Co}, \mathrm{Cr}$, $\mathrm{Cu}, \mathrm{Mn}, \mathrm{Ni}, \mathrm{Pb}, \mathrm{Sr}$, Th, U, W and $\mathrm{Zn}$ and metalloids As and $\mathrm{Sb}$ occur in soils of north of the open pit lake and dumps (Table 2, Fig. 2), because they were released from them, leaching through the two-mica granite mine area and retained in soils. The weathering of the host granite gave some contribution for the $\mathrm{U}$ and $\mathrm{Th}$ concentrations in soils, because $\mathrm{U}$ and $\mathrm{Th}$ occur in the accessory minerals, zircon, monazite, xenotime and apatite. The highest median values of $\mathrm{Fe}, \mathrm{As}, \mathrm{Co}, \mathrm{Cr}$, $\mathrm{Cu}, \mathrm{Ni}, \mathrm{Sr}$ and $\mathrm{Zn}$ occur at north. But the highest median values of $\mathrm{Mn}$ and $\mathrm{U}$ occur at south of the open pit lake and dumps, which is probably due to contamination by small local basic rock dykes containing uranium minerals associated with older quartz veins containing sulfides. There are also two other uranium mine areas: A-do-Cavalo at $50 \mathrm{~km}$ and Quinta das Vermelhas at $2.8 \mathrm{~km}$ at south of the studied area of Mortórios, and both contribute to increasing some metals and As concentrations in soils from south of the open pit lake and dumps.
The metals and metalloids are more mobile and available in acid than neutral conditions (Alloway 1995). At acid conditions $U$ is present as $\mathrm{UO}_{2}{ }^{2+}$, but under neutral conditions occurs as hydroxide complexes and its adsorption increases with the increase in the CEC. The maximum adsorption of $\mathrm{U}$ is at $\mathrm{pH} 5$ and then decreases up to 7.7 (Tserenpil et al. 2013). The acid $\mathrm{pH}$ of soils from the Mortórios area influences the capacity on the adsorption of metals and metalloids.

There were significant positive correlations ( $r>0.7$ at $5 \%$ significance level) between $\mathrm{Fe}$ and $\mathrm{Co}, \mathrm{Cr}, \mathrm{U}$ and $\mathrm{Ni}$, and between $\mathrm{Co}$ and $\mathrm{Cr}$ with $\mathrm{U}, \mathrm{Ni}$ and $\mathrm{Sr}$ (Table 3). These correlations could be associated with the occurrence of these metals in the uranium mine areas and their geochemical behavior. Some of these correlations were also found in other Portuguese abandoned uranium mine area (Neiva et al. 2015). The adsorption of arsenic by $\mathrm{Fe}$ oxides decreases above pH 7 (Goldberg 2002). The pH values of soils from Mortórios area range from 4.00 to 6.34, supporting that As is adsorbed by Fe-oxyhydroxides. Some metals $\mathrm{Co}, \mathrm{Cr}, \mathrm{U}$ and $\mathrm{Ni}$ are also adsorbed by Fe-oxyhydroxides (Table 3 ). The $\mathrm{Fe}$ concentration in the studied area is up to $67.7 \mathrm{~g} / \mathrm{kg}$ (Table 2). The $\mathrm{U}$ is incorporated in Fe oxides (Duff et al. 2002). The correlation analysis was applied to soils, from Minas Gerais (Brazil) with both low and high levels of Fe subjected to oxidizing conditions, and suggests that $\mathrm{Fe}$ concentrations are the main controlling agent for metals and the metalloid As (de Souza et al. 2015). The correlations between Co and Cr vs. U, Ni and Sr (Table 3) are due to weathering of basic rock dykes, which contain torbernite and autunite.

\section{Assessment of soil contamination}

The comparison (Fig. 3) of the histograms of the raw and compositional datasets shows that: (1) the raw dataset shows heavily skewed distributions for the four considered elements, biased mainly by the presence of outliers; (2) the compositional dataset allows to assume the assumption of normality for $\mathrm{U}$, As and Th. The Co is the exception, even if with a considerable decrease on the variation coefficient (Fig. 3). Thus, it is possible to reason that compositional data have two principal advantages, as it allows to work with proportions and at the same time improves data normalization. 


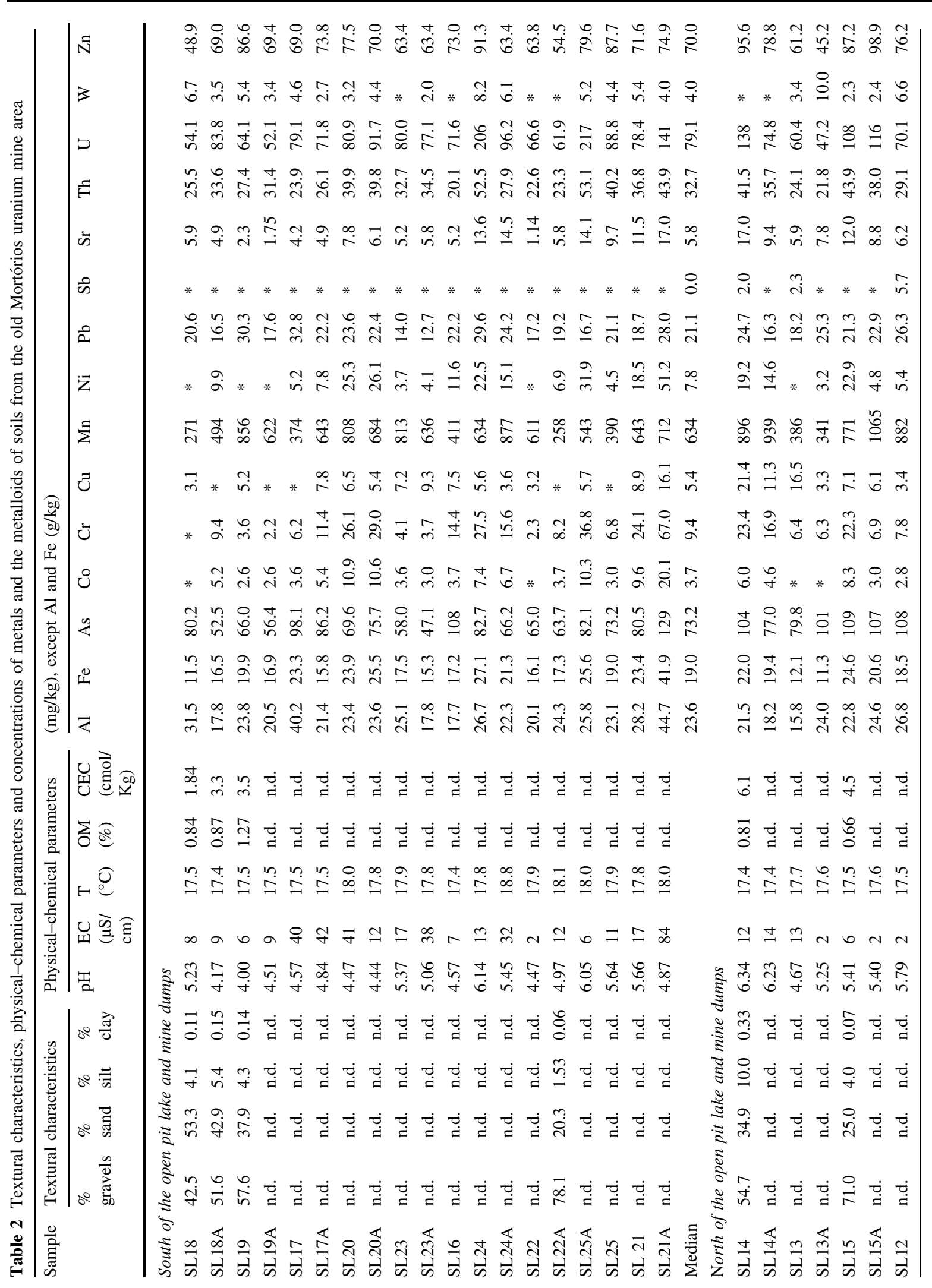




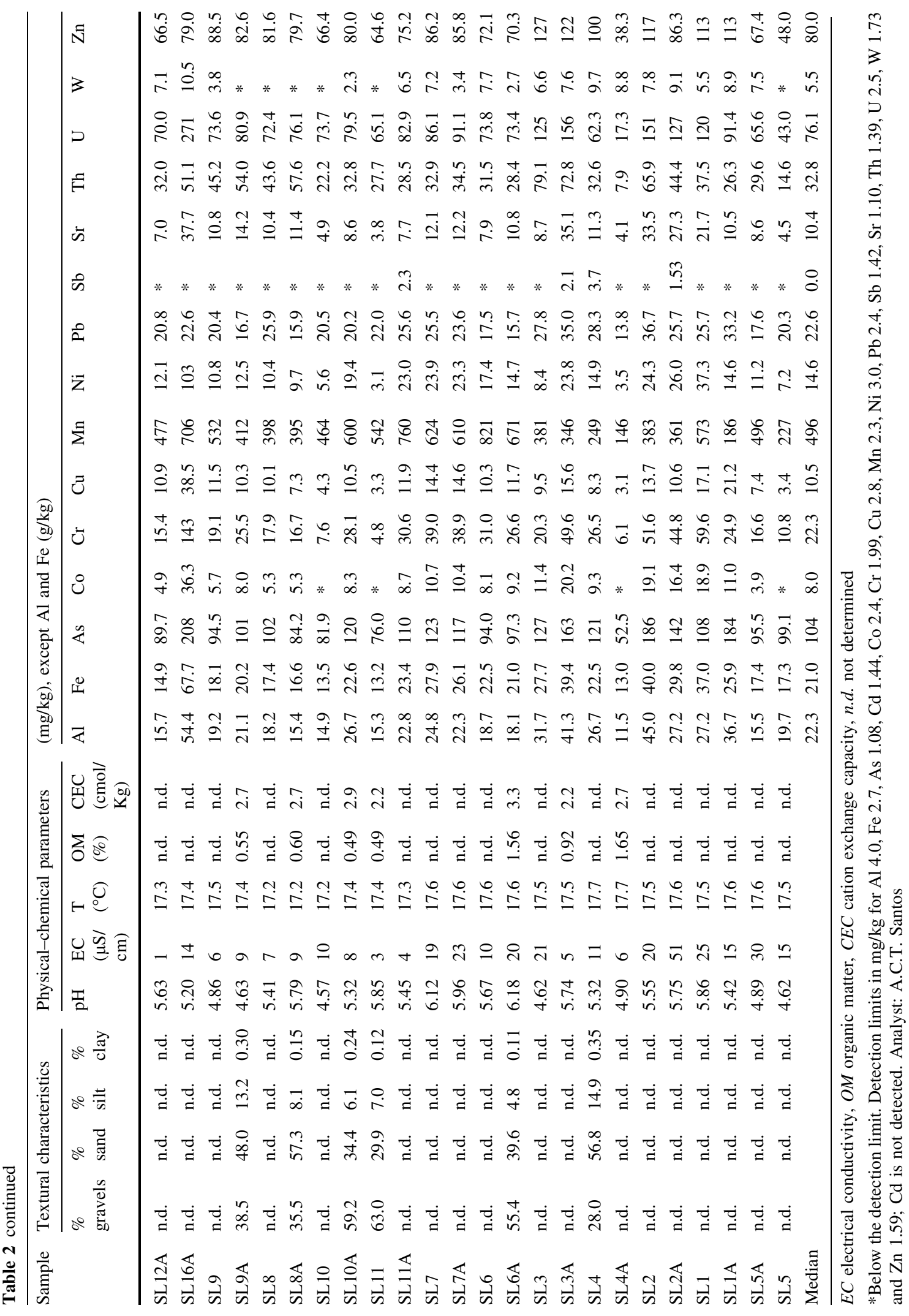





Fig. 2 Selected concentrations of metals and the metalloid As of soils from the abandoned Mortórios uranium mine area. a As, b Co, c Th, d U. Red dashed line: public, private and green areas and residential areas; Red solid line: commercial and industrial areas (Decreto Ministerial 1999). Blue dashed line: Swedish
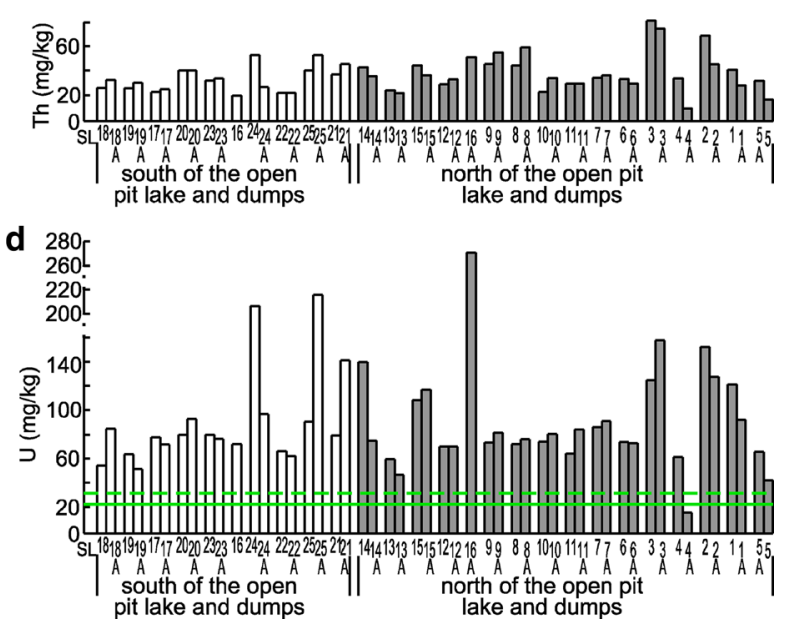

guidelines for soils (2009). Blue solid: line As for all purposes; Green solid line: $\mathrm{U}$ for agricultural and residential parkland uses; Green dashed line: U for commercial use (Canadian soil quality guidelines 2017)

Table 3 Correlation matrix (Spearman) in soils from the old Mortórios uranium mine area

\begin{tabular}{llllllllllllllll}
\hline & $\mathrm{Al}$ & $\mathrm{Fe}$ & $\mathrm{Mn}$ & $\mathrm{As}$ & $\mathrm{Co}$ & $\mathrm{Cr}$ & $\mathrm{Th}$ & $\mathrm{U}$ & $\mathrm{Cu}$ & $\mathrm{Ni}$ & $\mathrm{Pb}$ & $\mathrm{Sr}$ & $\mathrm{W}$ & $\mathrm{Zn}$ & $\mathrm{Sb}$ \\
\hline $\mathrm{Al}$ & $\mathbf{1}$ & & & & & & & & & & & & & \\
$\mathrm{Fe}$ & $\mathbf{0 . 7}$ & $\mathbf{1}$ & & & & & & & & & & & & & \\
$\mathrm{Mn}$ & 0.0 & 0.2 & $\mathbf{1}$ & & & & & & & & & & & \\
$\mathrm{As}$ & 0.5 & 0.6 & -0.1 & $\mathbf{1}$ & & & & & & & & & & & \\
$\mathrm{Co}$ & 0.6 & $\mathbf{0 . 9}$ & 0.1 & 0.6 & $\mathbf{1}$ & & & & & & & & & & \\
$\mathrm{Cr}$ & 0.4 & $\mathbf{0 . 8}$ & 0.1 & $\mathbf{0 . 7}$ & $\mathbf{0 . 9}$ & $\mathbf{1}$ & & & & & & & & \\
$\mathrm{Th}$ & 0.4 & 0.6 & 0.2 & 0.4 & $\mathbf{0 . 7}$ & 0.6 & $\mathbf{1}$ & & & & & & & \\
$\mathrm{U}$ & 0.5 & $\mathbf{0 . 8}$ & 0.3 & 0.5 & $\mathbf{0 . 8}$ & $\mathbf{0 . 7}$ & $\mathbf{0 . 7}$ & $\mathbf{1}$ & & & & & & & \\
$\mathrm{Cu}$ & 0.2 & 0.5 & 0.2 & 0.6 & $\mathbf{0 . 7}$ & $\mathbf{0 . 7}$ & 0.4 & 0.4 & $\mathbf{1}$ & & & & & & \\
$\mathrm{Ni}$ & 0.4 & $\mathbf{0 . 8}$ & 0.2 & 0.6 & $\mathbf{0 . 9}$ & $\mathbf{0 . 9}$ & 0.6 & $\mathbf{0 . 7}$ & 0.6 & $\mathbf{1}$ & & & & & \\
$\mathrm{Pb}$ & 0.6 & 0.6 & -0.1 & 0.6 & 0.4 & 0.4 & 0.2 & 0.4 & 0.2 & 0.3 & $\mathbf{1}$ & & & & \\
$\mathrm{Sr}$ & 0.5 & $\mathbf{0 . 7}$ & 0.1 & 0.6 & $\mathbf{0 . 8}$ & $\mathbf{0 . 8}$ & $\mathbf{0 . 7}$ & $\mathbf{0 . 7}$ & 0.6 & $\mathbf{0 . 8}$ & 0.3 & $\mathbf{1}$ & & & \\
$\mathrm{W}$ & 0.5 & 0.4 & -0.2 & 0.4 & 0.4 & 0.3 & 0.1 & 0.2 & 0.2 & 0.3 & 0.5 & 0.3 & $\mathbf{1}$ & & \\
$\mathrm{Zn}$ & 0.5 & 0.7 & 0.1 & 0.6 & 0.6 & 0.6 & $\mathbf{0 . 7}$ & 0.6 & 0.5 & 0.5 & 0.6 & 0.6 & 0.2 & $\mathbf{1}$ & \\
$\mathrm{Sb}$ & 0.1 & 0.1 & 0.0 & 0.3 & 0.1 & 0.2 & 0.0 & 0.0 & 0.3 & 0.1 & 0.3 & 0.2 & 0.2 & 0.2 & $\mathbf{1}$ \\
\hline
\end{tabular}

The highest Spearman correlation value with a significance level of 0.05 are given in bold

Spatial modeling-geostatistical approach

For spatial modeling, U, As, Co and Th were chosen as they are core in contamination forecasts, associated with uranium mining. The spatial stochastic patterns of the four chosen contamination indicators were performed following a two-step geostatistical modeling approach: (1) structural analysis (variography) and (2) spatial estimation through ordinary kriging (OK). 

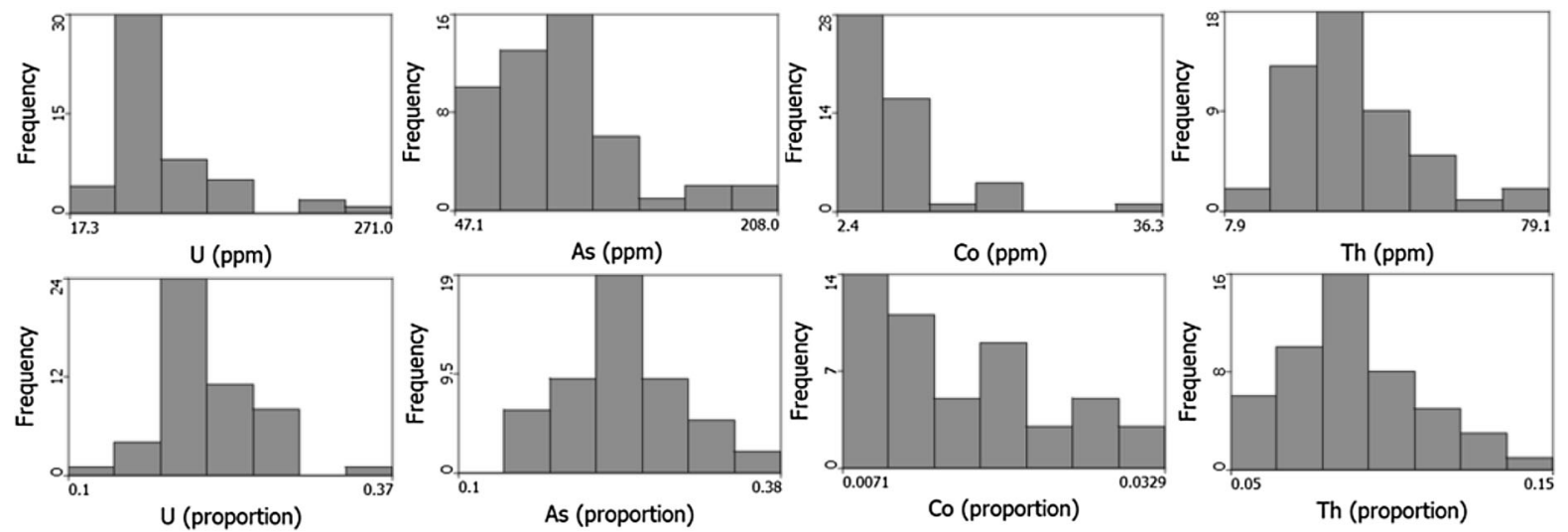

Fig. 3 Raw data histograms for U, As, Co and Th (ppm) and compositional data histograms for U, As, Co and Th (\%)

The semi-variogram is a vectoral function applied to compute the spatial variability of a specific regionalized variable, defined as follows (Matheron 1963; Journel and Huijbregts 1978):

$\gamma(h)=\frac{1}{2 N(h)} \sum_{2 N(h)}^{N(h)}\left[Z\left(x_{i}\right)-Z\left(x_{i}+h\right)\right]^{2}$

The distance is represented by $\boldsymbol{h}$, where $\boldsymbol{Z}\left(\boldsymbol{x}_{\boldsymbol{i}}\right)$ and $\boldsymbol{Z}\left(\boldsymbol{x}_{\boldsymbol{i}}+\boldsymbol{h}\right)$ are the values assumed by the observed variable at points $\boldsymbol{x}_{\boldsymbol{i}}$, and $\boldsymbol{x}_{\boldsymbol{i}}+\boldsymbol{h}$. Indeed, it is the average value of the square differences, for an assemble of pairs of points, within a survey field at an $\boldsymbol{h}$ distance. The obtained variograms provide information about the spatial structure of the attribute at study. The nugget effect $\left(\boldsymbol{C}_{\mathbf{0}}\right)$, represents the behavior at short distances. The sill $\left(\boldsymbol{C}_{\mathbf{1}}\right)$ and the amplitude (a) define, respectively, the used inertia in the inference process and the radius of influence for each of the considered variables.

Theoretical models $\gamma^{*}(h)$ were fitted to the experimental functions for the raw and the compositional data (Isaaks and Srivastava 1989). The omnidirectional (isotropic structures) variograms obtained show, generally, a better fitting for the compositional dataset (Fig. 4). Therefore, the interpolation procedure's (OK) error is minimized when using the compositional dataset.

The distribution patterns were than computed using OK (Fig. 5). Evident contrasts are noteworthy when analyzing the maps obtained for the raw and the compositional datasets. Indeed, a careful interpretation of these representations must be done, as they support distinct data and, therefore, different information. The RD's spatial patterns show the stochastic approach of the elements concentration distributions and targeting hotspots location for these contaminants. On the other hand, the CD's mapping allowed the visualization of proportions' spatial variability and, therefore, providing an important insight in contaminant fate, within the study area.

The contaminants higher concentrations (hotspots) are located north and northwest in the survey area (Fig. 5). However, it is in the south-southeast segment where the highest proportion on $\mathrm{U}$ - up to $33 \%$; Asup to $35 \%$ and $\mathrm{Th}$ - up to $13 \%$ can be found. The Co relative enrichment is not relevant-up to $2.8 \%$. The results lead to conclude that the old mining activity inflicted the depletion on $\mathrm{U}$, As and Th concentrations. However, the high proportions on these elements, observed in the southeast segment, lead to consider that the fate of these contaminants shows a clear spatial trend and, therefore, a prevalent direction for contamination and local concentration (relative enrichment). Uranium is significantly more soluble than Th in moderately acidic soils, which justify the $U$ prevalent direction of contamination to southeast part (Ahmed et al. 2012).

The studied soil samples from south and north of the open pit lake and dumps of the old Mortórios uranium mine area record As concentrations of $47.1-129 \mathrm{mg} / \mathrm{kg}$ and $52.5-208 \mathrm{mg} / \mathrm{kg}$, respectively, which are higher than $1-20 \mathrm{mg} / \mathrm{kg}$ As for typical uncontaminated agricultural soils (Adriano 2001). They exceed the Italian guideline limits (Decreto Ministerial 1999) for public, private and green areas and residential areas $(20 \mathrm{mg} / \mathrm{kg})$ and generally for commercial and industrial areas (50 mg/kg) (Fig. 2a). 
Fig. 4 Omnidirectional experimental variograms and correspondent fitted models for raw and compositional data
RAW DATA
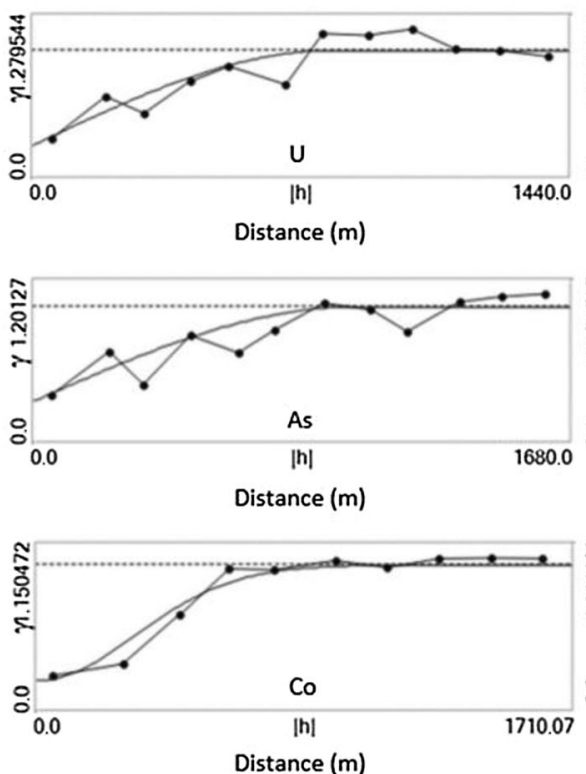

Distance $(m)$



COMPOSITIONAL DATA
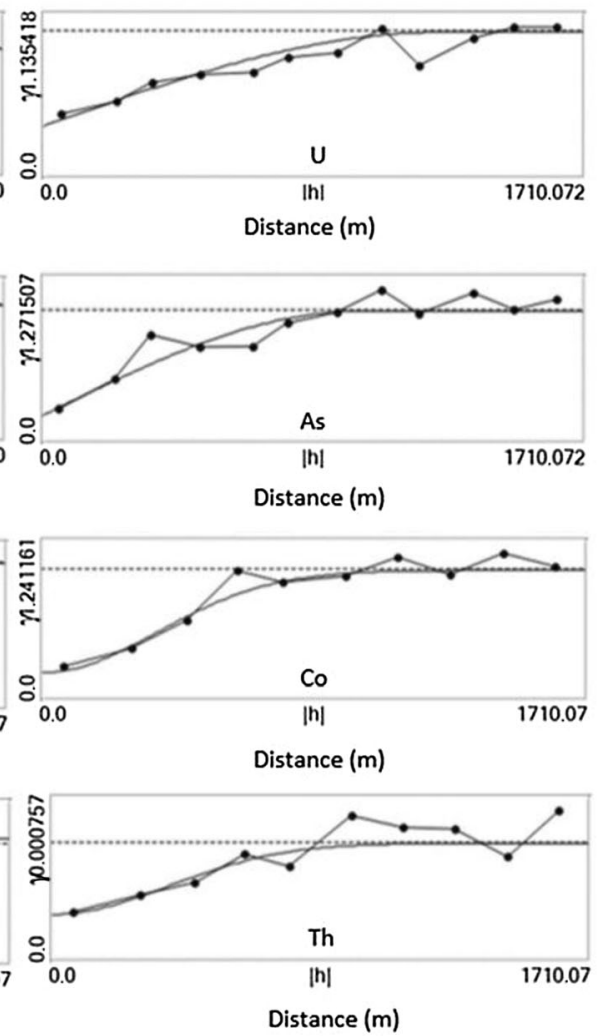

They also have higher As concentrations than $10 \mathrm{mg} /$ $\mathrm{kg}$ (Fig. 2a) indicated for sensitive land use (Swedish guidelines for soils 2009) and $12 \mathrm{mg} / \mathrm{kg}$ for agricultural, residential parkland, commercial and industrial uses of the Canadian soil quality guidelines (2017). The different physical and chemical properties of soils control the fraction of As in soils available to plants.

The studied soil samples from south and north of the Mortórios area also have $52.1-217 \mathrm{mg} / \mathrm{kg}$ and $17.3-271 \mathrm{mg} / \mathrm{kg}$ concentrations of $\mathrm{U}$, respectively, which are generally higher than $23 \mathrm{mg} / \mathrm{kg}$ (Fig. 2d) for agricultural and residential parkland uses and $33 \mathrm{mg} / \mathrm{kg}$ for commercial use, according to the Canadian guidelines (2017). One soil sample from south and four soil samples from north soil samples have Co concentrations of $16.4-36.3 \mathrm{mg} / \mathrm{kg}$, which exceed that of $15 \mathrm{mg} / \mathrm{kg}$ (Fig. 2b) of the Swedish guidelines for soils (2009).

Two contamination factors were calculated. $\mathrm{Pi}=$ $\mathrm{Ci} / \mathrm{Bi}$ where $\mathrm{Ci}$ is the measured concentration of the pollutant and $\mathrm{Bi}$ is the natural background level, which gives for most metals and As the baseline values given by median for values for $<2.00 \mathrm{~mm}$ Portuguese topsoil's of Al-1.73\%, As- $9 \mathrm{mg} / \mathrm{kg}, \mathrm{Co}-8 \mathrm{mg} / \mathrm{kg}$, Cr$21 \mathrm{mg} / \mathrm{kg}, \mathrm{Cu}-16 \mathrm{mg} / \mathrm{kg}, \mathrm{Fe}-2.22 \%, \mathrm{Mn}-370 \mathrm{mg} / \mathrm{kg}$, $\mathrm{Ni}-14 \mathrm{mg} / \mathrm{kg}, \mathrm{Pb}-15 \mathrm{mg} / \mathrm{kg}, \quad \mathrm{Sr}-9 \mathrm{mg} / \mathrm{kg}$ and $\mathrm{Zn}-$ $45 \mathrm{mg} / \mathrm{kg}$ (Inácio et al. 2008). However, the Ci value for U of Portuguese topsoil's is unavailable. Therefore, the $\mathrm{Ci}$ baseline of $\mathrm{U}$ for granitic subsoil, without the influence of the soil formation and anthropogenic processes, from three Spanish areas at West of Salamanca and not far from the Mortórios area in Portugal (Fig. 1a) with the value of $29.8 \mathrm{mg} / \mathrm{kg}$ (Santos-Francés et al. 2018) was used. The $40.8 \mathrm{mg} /$ $\mathrm{kg}$ for Th of the C horizon PCG (porphyritic coarsegrained granite) developed on granites of the $\mathrm{NW}$ Spain (Taboada et al. 2006) (Fig. 1a) was used because it is from a granitic subsoil. The Pi pollution percentage increases for $\mathrm{As}, \mathrm{Co}, \mathrm{Fe}, \mathrm{Cr}, \mathrm{Cu}, \mathrm{Ni}, \mathrm{Pb}, \mathrm{Sr}$, $\mathrm{Th}, \mathrm{U}$ and decreases for $\mathrm{Al}, \mathrm{Mn}$ and $\mathrm{Zn}$ from south soils to north soils of the open pit lake and dumps from the Mortórios uranium mine area (Table 4). South soils present mainly low pollution percentage of Co, $\mathrm{Cr}, \mathrm{Cu}, \mathrm{Fe}, \mathrm{Ni}, \mathrm{Sr}$ and $\mathrm{Th}$, but moderate pollution of $\mathrm{Al}$, 
Fig. 5 Ordinary kriging results. Distribution patterns for raw data (RD) and compositional data (CD). Scale is expressed in ppm (RD) and in \% (CD)

\section{Raw data (RD)}


U Compositional data (CD)
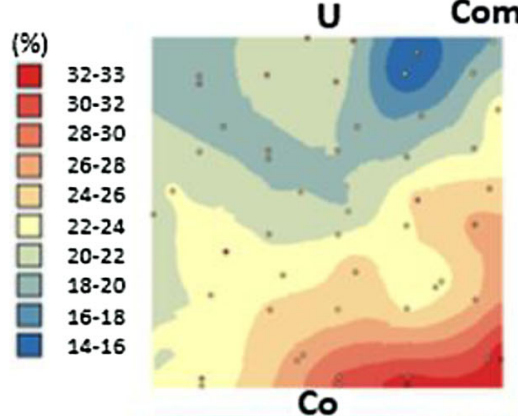

(\%)
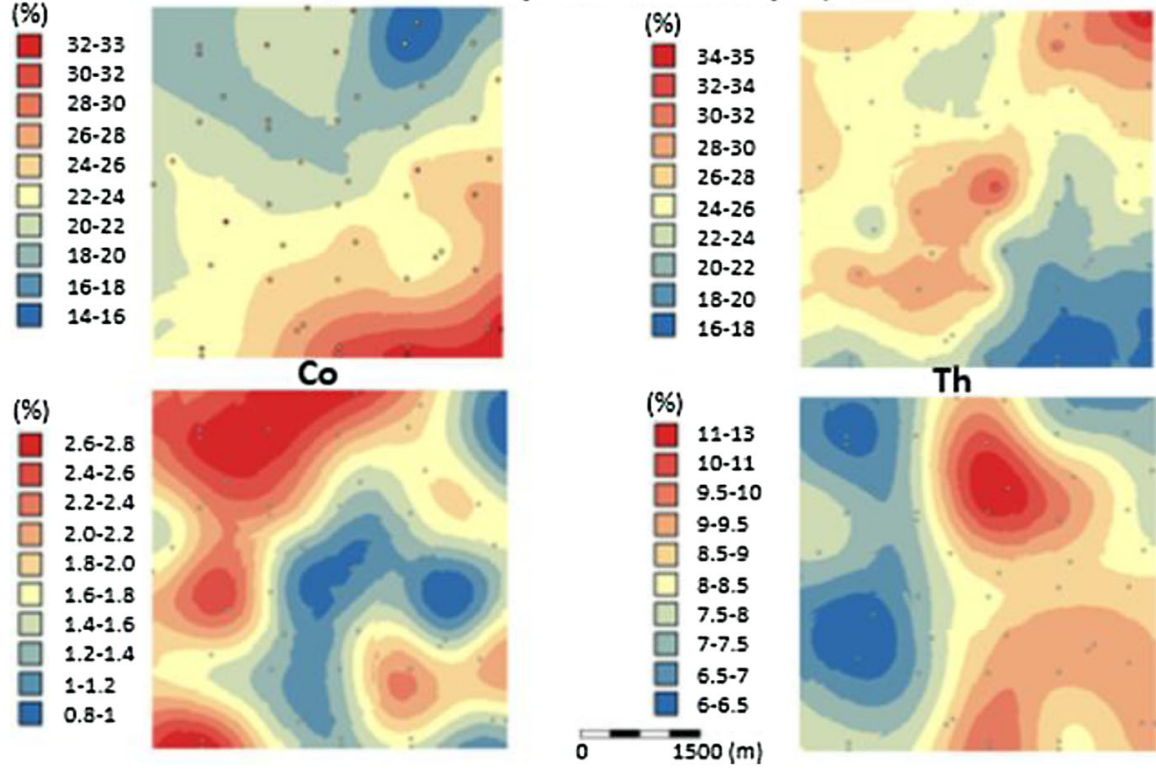

Th

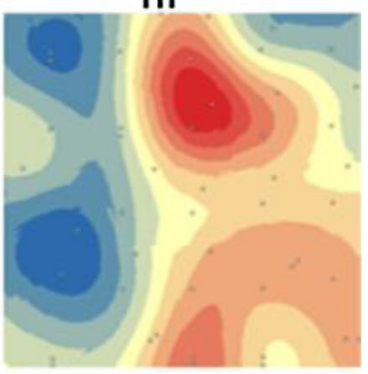

$\mathrm{Mn}, \mathrm{Pb}, \mathrm{U}$ and $\mathrm{Zn}$ and only very high pollution percentage of As. The north soils have mainly low pollution percentage of $\mathrm{Cu}$ and $\mathrm{Th}$, moderate pollution percentage of $\mathrm{Al}, \mathrm{Co}, \mathrm{Cr}, \mathrm{Mn}, \mathrm{Pb}, \mathrm{Ni}, \mathrm{U}$ and $\mathrm{Zn}$ and very high pollution of $\mathrm{Al}$, As and $\mathrm{Fe}$.

The other contamination factor is the Igeo $=\log _{2}(-$ $\mathrm{Ci} / 1.50 \mathrm{Bi}$ ) with $\mathrm{Ci}-$ the measured concentration of metal or metalloid $\mathrm{i}$ in the soil and $\mathrm{Bi}$ is the geological background level of the metal or metalloid i. The pollution percentage based on the Igeo increases for As, $\mathrm{Co}, \mathrm{Cr}, \mathrm{Fe}, \mathrm{Pb}, \mathrm{Sr}$, Th and $\mathrm{Zn}$ from south soils to north soils of the open pit lake and dumps from the old Mortórios uranium mine area (Table 5). The increases in $\mathrm{As}, \mathrm{Pb}, \mathrm{Fe}$ and $\mathrm{Zn}$ are mainly due to the weathering of sulfides from the quartz veins. The increases in Co and $\mathrm{Cr}$ are due to the weathering of basic rock dykes. 
Table 4 The pollution percentage based on the factor Pi of soils from the old Mortórios uranium mine area. (Modified from Santos-Francés et al. 2018)

$\mathrm{Pi}<1$-low pollution; $1=\mathrm{Pi}<3$-moderate pollution; $3=\mathrm{Pi}<6$-high pollution; $\mathrm{Pi} \geq 6$-very high pollution

\begin{tabular}{lrrrrrrrrrrrrr}
\hline Pollution $\%$ & $\mathrm{Al}$ & $\mathrm{As}$ & $\mathrm{Co}$ & $\mathrm{Cr}$ & $\mathrm{Cu}$ & $\mathrm{Fe}$ & $\mathrm{Mn}$ & $\mathrm{Ni}$ & $\mathrm{Pb}$ & $\mathrm{Sr}$ & $\mathrm{Th}$ & $\mathrm{U}$ & $\mathrm{Zn}$ \\
\hline \multicolumn{2}{l}{ South of the open pit lake and mine dumps } \\
Low & 0 & 0 & 71 & 72 & 93 & 63 & 11 & 53 & 11 & 68 & 84 & 0 & 0 \\
Moderate & 100 & 0 & 29 & 28 & 7 & 37 & 89 & 40 & 89 & 32 & 16 & 74 & 100 \\
High & 0 & 11 & 0 & 0 & 0 & 0 & 0 & 7 & 0 & 0 & 0 & 16 & 0 \\
Very high & 0 & 89 & 0 & 0 & 0 & 0 & 0 & 0 & 0 & 0 & 0 & 10 & 0 \\
North of the open pit lake & and mine & dumps & & & & & & & & & \\
Low & 23 & 0 & 41 & 48 & 84 & 55 & 26 & 47 & 3 & 45 & 65 & 3 & 3 \\
Moderate & 77 & 0 & 55 & 49 & 16 & 42 & 74 & 50 & 97 & 42 & 35 & 62 & 97 \\
High & 0 & 0 & 4 & 0 & 0 & 3 & 0 & 0 & 0 & 13 & 0 & 32 & 0 \\
Very high & 0 & 100 & 0 & 3 & 0 & 0 & 0 & 3 & 0 & 0 & 0 & 3 & 0 \\
\hline
\end{tabular}

The small increase in Th is attributed to the weathering of basic rock dykes. South soils and north soils are mainly non-contaminated in $\mathrm{Co}, \mathrm{Cr}, \mathrm{Cu}, \mathrm{Sr}$ and $\mathrm{Th}$, mildly contaminated in $\mathrm{U}$ and $\mathrm{Zn}$ and strongly contaminated in As (Table 5).

The $U$ is much more leached from the open pit lake and dumps and adsorbed by Fe-oxyhydroxides than Th (Table 2, Fig. 2c, d), because $\mathrm{U}$ is more abundant than Th. The Th is generally more resistant to weathering than U (e.g., Négrel et al. 2018). The acid pH (4.00-6.34) of the Mortórios soils increases the mobility of toxic elements (Loska et al. 2004).

Comparison of contaminations in soils from two

Portuguese uranium mine areas exploited from open pits

The old Mondego Sul uranium mine area produced 75 tonnes of $\mathrm{U}_{3} \mathrm{O}_{8}$ from 1987 to 1991 (Neiva et al. 2016). Therefore, it produced more 48 tonnes of $\mathrm{U}_{3} \mathrm{O}_{8}$ for 4 years than the old Mortórios uranium mine area for 6 years. The Mondego Sul mine consists of quartz veins containing sulfides and autunite, torbernite, meta-uranocircite and meta-saleeite, whereas the Mortórios uranium mine consists of weathered basic rock dykes containing torbernite and autunite associated with older quartz veins containing sulfides. The soil data from the old Mondego Sul uranium mine area belong to 15 samples from outside and 36 samples from inside the mine influence area. In general, soils from south and north of the open pit lake and dumps from Mortórios present lower median values for metals and metalloids than those of soils from outside and inside the mine influence area of Mondego Sul (Table 6), except for Mn.

Soils from the old Mondego Sul uranium mine area are contaminated in As, contain $70.4-147 \mathrm{mg} / \mathrm{kg}$ and $47.5-223 \mathrm{mg} / \mathrm{kg}$ from outside and inside the mine influence area, respectively (Table 6) and may not have any use according to the Decreto Ministerial (1999), Swedish guidelines for soils (2009) and Canadian soil quality guidelines (2017). They also contain $27.4-152 \mathrm{mg} / \mathrm{kg}$ of $U$ from outside and $51.8-377 \mathrm{mg} / \mathrm{kg}$ of $\mathrm{U}$ from inside the mine influence area (Table 6) and may not also be used for agricultural, parkland and commercial uses according to the Canadian soil guidelines (2017). Some soil samples from inside the mine influence area also have a higher $\mathrm{U}$ concentration than the accepted value for industrial use $(300 \mathrm{mg} / \mathrm{kg})$, indicated by the Canadian guidelines (2017). Some soil samples from outside and inside also have higher $\mathrm{Pb}$ concentrations and a few soil samples from inside present higher Co rarely $\mathrm{Sb}$ concentrations than those of $\mathrm{Pb}(100 \mathrm{mg} / \mathrm{kg}), \mathrm{Co}$ $(20 \mathrm{mg} / \mathrm{kg})$ and $\mathrm{Sb}(10 \mathrm{mg} / \mathrm{kg})$ indicated by the Decreto Ministerial (1999) (Table 6). Some soil samples from outside and inside the mine influence area have higher $\mathrm{Ni}, \mathrm{Pb}$ and $\mathrm{Zn}$ concentrations and some soil samples from inside also present higher Co concentrations than those of Co $(15 \mathrm{mg} / \mathrm{kg})$, Ni (40 mg/kg), Pb (50 mg/kg), Zn (250 mg/kg) given by the Swedish guidelines (2009) (Table 6). Some soil samples from outside and inside the mine influence area have higher $\mathrm{Cr}, \mathrm{Ni}, \mathrm{Pb}$ and $\mathrm{Zn}$ concentrations than those for agricultural and residential parkland uses $(\mathrm{Cr}$ 64 mg/kg; Ni 45 mg/kg; Pb 70 mg/kg, 140 mg/kg; Zn 
Table 5 The pollution percentage based on the geo-accumulation index Igeo of soils from the old Mortórios uranium mine area

\begin{tabular}{|c|c|c|c|c|c|c|c|c|c|c|c|c|c|}
\hline Pollution \% & $\mathrm{Al}$ & As & Co & $\mathrm{Cr}$ & $\mathrm{Cu}$ & $\mathrm{Fe}$ & $\mathrm{Mn}$ & $\mathrm{Ni}$ & $\mathrm{Pb}$ & $\mathrm{Sr}$ & $\mathrm{Th}$ & $\mathrm{U}$ & $\mathrm{Zn}$ \\
\hline \multicolumn{14}{|c|}{ South of the open pit lake and mine dumps } \\
\hline Class 0 & 74 & 0 & 94 & 89 & 100 & 95 & 37 & 53 & 68 & 79 & 100 & 0 & 32 \\
\hline Class 1 & 26 & 0 & 6 & 6 & 0 & 5 & 63 & 40 & 32 & 21 & 0 & 74 & 68 \\
\hline Class 2 & 0 & 5 & 0 & 5 & 0 & 0 & 0 & 7 & 0 & 0 & 0 & 16 & 0 \\
\hline Class 3 & 0 & 90 & 0 & 0 & 0 & 0 & 0 & 0 & 0 & 0 & 0 & 10 & 0 \\
\hline Class 4 & 0 & 5 & 0 & 0 & 0 & 0 & 0 & 0 & 0 & 0 & 0 & 0 & 0 \\
\hline Class 5 & 0 & 0 & 0 & 0 & 0 & 0 & 0 & 0 & 0 & 0 & 0 & 0 & 0 \\
\hline Class 6 & 0 & 0 & 0 & 0 & 0 & 0 & 0 & 0 & 0 & 0 & 0 & 0 & 0 \\
\hline \multicolumn{14}{|c|}{ North of the open pit lake and mine dumps } \\
\hline Class 0 & 68 & 0 & 80 & 77 & 97 & 87 & 58 & 70 & 48 & 77 & 90 & 7 & 26 \\
\hline Class 1 & 29 & 0 & 16 & 20 & 3 & 13 & 42 & 27 & 52 & 10 & 10 & 58 & 74 \\
\hline Class 2 & 3 & 3 & 4 & 0 & 0 & 0 & 0 & 0 & 0 & 13 & 0 & 32 & 0 \\
\hline Class 3 & 0 & 55 & 0 & 3 & 0 & 0 & 0 & 3 & 0 & 0 & 0 & 3 & 0 \\
\hline Class 4 & 0 & 42 & 0 & 0 & 0 & 0 & 0 & 0 & 0 & 0 & 0 & 0 & 0 \\
\hline Class 5 & 0 & 0 & 0 & 0 & 0 & 0 & 0 & 0 & 0 & 0 & 0 & 0 & 0 \\
\hline Class 6 & 0 & 0 & 0 & 0 & 0 & 0 & 0 & 0 & 0 & 0 & 0 & 0 & 0 \\
\hline
\end{tabular}

Class 0 , Igeo $<0$, non-contaminated; class $1,0=$ Igeo $<1$, from mildly contaminated; class $2,1=$ Igeo $<2$ to moderately contaminated; class 3, 2 = Igeo $<3$, to strongly contaminated; class 4, $3=$ Igeo $<4$, and strongly contaminated; class 5 , Igeo $<5$, from heavily contaminated; class 6 , Igeo $\geq 5$, to extremely contaminated. (e.g., Santos-Francés et al. 2018)

$200 \mathrm{mg} / \mathrm{kg}$ ) given by the Canadian guidelines (2017) (Table 6). Therefore, soils from Mondego Sul area are more contaminated than those from the Mortorios area. However, in both areas the main contaminators are arsenic and uranium. At the former U site at Kadji Sai, Kyrgyzstan, the soils were also mainly enriched in $\mathrm{U}$ and As (Lind et al. 2013).

The Pi factor shows increases in the pollution percentages of $\mathrm{Co}, \mathrm{Cr}, \mathrm{Fe}, \mathrm{Cu}, \mathrm{Mn}, \mathrm{Ni}, \mathrm{Pb}, \mathrm{Sr}$ and $\mathrm{U}$ increases from the soils outside to soils inside the mine influence area from the old Mondego Sul uranium mine area (Table 7). These behaviors are due to the weathering of quartz veins containing sulfides and uranium minerals. The outside soils and inside soils have mainly low pollution percentages of $\mathrm{Mn}$ and $\mathrm{Sr}$, which also occur in Co from outside soils. They also have moderate pollution percentages in $\mathrm{Al}, \mathrm{Cr}, \mathrm{Cu}, \mathrm{Fe}$ and $\mathrm{Zn}$, but they also occur in $\mathrm{Co}$ and $\mathrm{Ni}$ in inside soils. The high pollution percentages are recorded for $\mathrm{Pb}, \mathrm{Th}$ and $\mathrm{U}$ in soils from outside and $\mathrm{Th}, \mathrm{U}$ and $\mathrm{Zn}$ in soils from inside. In general, the $\mathrm{Pi}$ factor percentage presents higher contamination mainly in soils from the
Mondego Sul area than in the soils from the Mortórios area (Tables 4, 7), which can be explained by the significant higher exploitation in the former area than in the latter one.

The Igeo pollution percentage shows increase in $\mathrm{Co}, \mathrm{Cu}, \mathrm{Fe}, \mathrm{Mn}, \mathrm{Ni}, \mathrm{Pb}$, Th and $\mathrm{U}$ and decrease in $\mathrm{Cr}$ from soils of outside to soils of inside of the mine influence area from the Mondego Sul uranium mine area (Table 8). Outside soils from the Mondego Sul area are mainly non-contaminated in $\mathrm{Co}, \mathrm{Cu}, \mathrm{Fe}, \mathrm{Mn}$, $\mathrm{Ni}$, and $\mathrm{Sr}$, mildly contaminated in $\mathrm{Al}, \mathrm{Cr}$, Th and $\mathrm{Zn}$, to moderately contaminated in $\mathrm{Pb}$ and $\mathrm{U}$ and strongly contaminated in As. The inside soils are mainly noncontaminated in $\mathrm{Fe}, \mathrm{Co}, \mathrm{Mn}$ and $\mathrm{Sr}$, mildly contaminated in $\mathrm{Al}, \mathrm{Cr}, \mathrm{Cu}, \mathrm{Ni}$ and $\mathrm{Zn}$, moderately contaminated in $\mathrm{Pb}$, Th and $\mathrm{U}$ and strongly contaminated in As. The Igeo factor percentage shows higher contamination of $\mathrm{Al}, \mathrm{As}, \mathrm{Cr}, \mathrm{Cu}, \mathrm{Pb}, \mathrm{Th}, \mathrm{U}$ and $\mathrm{Zn}$ in outside and inside the mine influence area in soils from the Mondego Sul area than in the soils from south and north of the open pit lake and dumps of the Mortórios area (Tables 5 and 8 ). 
Table 6 Comparison of the values, of some metals and the metalloid As of the soil from the two abandoned uranium mines areas, before the remediation, with Portuguese background and FOREGS values, and with the limits of Canadian and Italian legislation

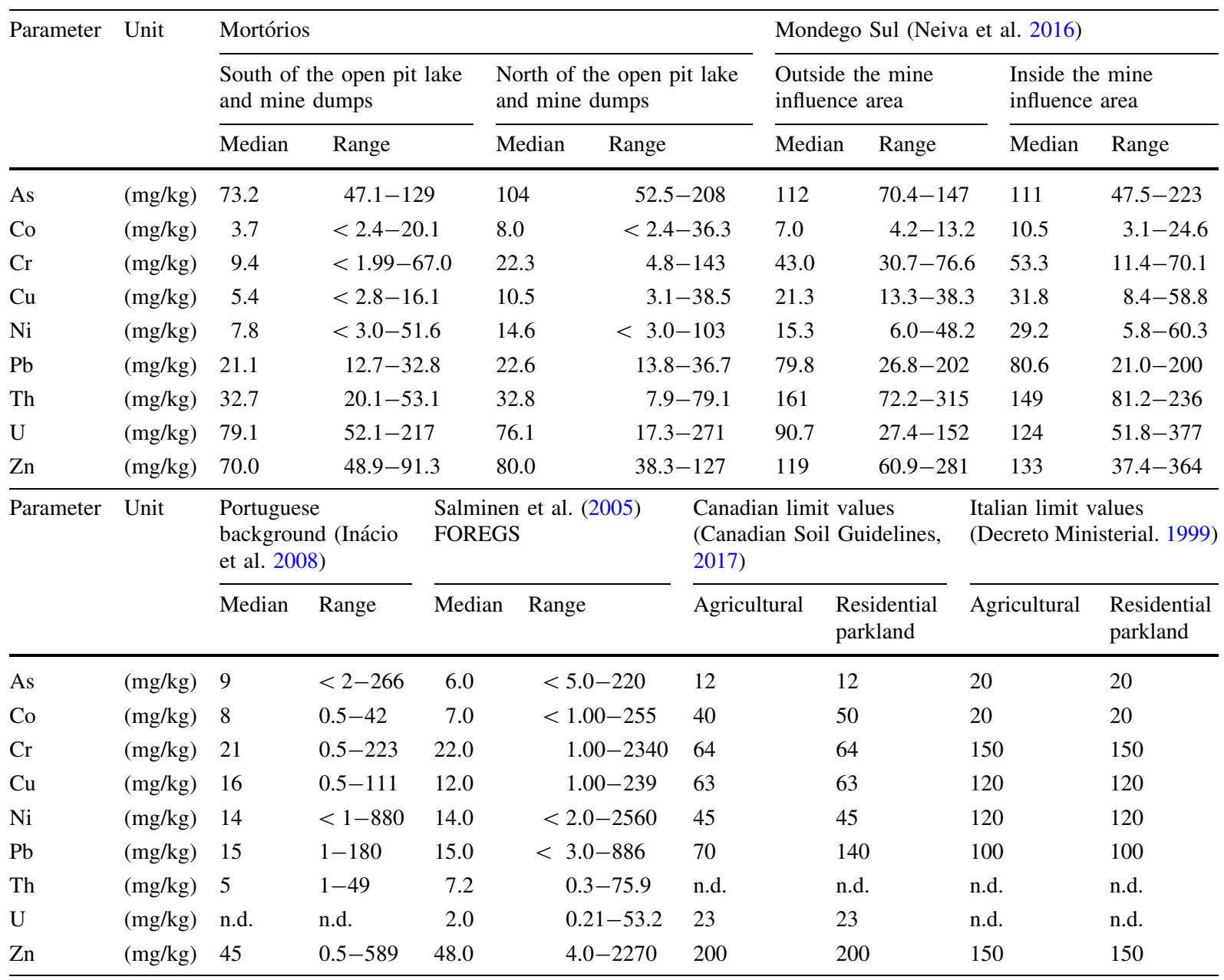

n.d. not defined

Table 7 The pollution percentage based on the factor Pi of soils from the old Mondego Sul uranium mine area

Classes as in Table 4

\begin{tabular}{lrrrrrrrrrrrrr}
\hline Pollution $\%$ & $\mathrm{Al}$ & $\mathrm{As}$ & $\mathrm{Co}$ & $\mathrm{Cr}$ & $\mathrm{Cu}$ & $\mathrm{Fe}$ & $\mathrm{Mn}$ & $\mathrm{Ni}$ & $\mathrm{Pb}$ & $\mathrm{Sr}$ & $\mathrm{Th}$ & $\mathrm{U}$ & $\mathrm{Zn}$ \\
\hline Outside the mine influence area & & & & & & & & & \\
Low & 7 & 0 & 67 & 0 & 20 & 40 & 87 & 47 & 7 & 93 & 0 & 7 & 0 \\
Moderate & 93 & 0 & 33 & 93 & 80 & 60 & 13 & 47 & 0 & 7 & 20 & 33 & 60 \\
High & 0 & 0 & 0 & 7 & 0 & 0 & 0 & 6 & 60 & 0 & 53 & 60 & 33 \\
Very high & 0 & 100 & 0 & 0 & 0 & 0 & 0 & 0 & 33 & 0 & 27 & 0 & 7 \\
inside the mine & influence & area & & & & & & & & & & & \\
Low & 6 & 0 & 28 & 3 & 8 & 17 & 80 & 14 & 0 & 83 & 0 & 0 & 3 \\
Moderate & 94 & 0 & 69 & 78 & 81 & 80 & 17 & 72 & 22 & 17 & 19 & 17 & 50 \\
High & 0 & 3 & 3 & 19 & 11 & 0 & 3 & 14 & 36 & 0 & 81 & 58 & 42 \\
Very high & 0 & 97 & 0 & 0 & 0 & 0 & 0 & 0 & 42 & 0 & 0 & 25 & 5 \\
\hline
\end{tabular}


Table 8 The pollution percentage based on the geo-accumulation index Igeo of soils from the old Mondego Sul uranium mine area

Classes as in Table 5

\section{Conclusions}

At the old Mortórios uranium mine area, soils in the northern vicinity of the open pit lake and dumps have the highest concentrations of $\mathrm{Fe}, \mathrm{Co}, \mathrm{Cr}, \mathrm{Cu}, \mathrm{Mn}, \mathrm{Ni}$, $\mathrm{Pb}, \mathrm{Sr}, \mathrm{Th}, \mathrm{U}, \mathrm{W}$ and $\mathrm{Zn}$ and the highest median values of $\mathrm{Fe}, \mathrm{As}, \mathrm{Co}, \mathrm{Cr}, \mathrm{Cu}, \mathrm{Ni}, \mathrm{Sr}$ and $\mathrm{Zn}$, because they were leached from weathered basic rock dikes containing torbernite and autunite and older quartz veins containing sulfides. However, the highest median values of $\mathrm{U}$ and $\mathrm{Mn}$ occur at south of the open pit lake and dumps.

The contaminants higher concentrations-hotspots-are located north and northwest in the survey area. However, it is in the south-southeast segment where the highest proportion on U-up to 33\%; Asup to $35 \%$ and Th-up to $13 \%$ are achieved. However, when analyzing the proportions, a clear concentration on U, As, and Th is settled in the southeast part. Therefore, the fate of these contaminants has a clear spatial southeast trend for contamination and relative enrichment on these elements.

The Mortórios area is less contaminated than the old Mondego Sul uranium mine area, before the remediation, where the main contamination is also due to the As and U concentration. The Mondego Sul area also presents contamination in other metals, such as $\mathrm{Co}, \mathrm{Cu}, \mathrm{Pb}$ and the metalloid $\mathrm{Sb}$. The different contamination in the two areas are attributed to the different production of $\mathrm{U}_{3} \mathrm{O}_{8}$ tonnes, which are certainly due to the different origin of the two uranium mineralizations. At Mortórios, autunite and torbernite occur in basic rock dykes which are associated with older quartz veins containing sulfides. However, at Mondego Sul the same uranium minerals occur and meta-uranocircite and meta-saleeite were found and all belong to quartz veins containing sulfides.

The old Mondego Sul area is being remediated. The old Mortórios area must also be remediated.

Acknowledgements This research was supported by the Fundação para a Ciência e a Tecnologia through projects UID/ GEO/04035/201C and UID/MAR/04292/2013-MARE (PPC). Boente obtained a grant from the "Formación del Profesorado Universitario" program, financed by the "Ministerio de Educación, Cultura y Deporte de España." M.T.D Albuquerque acknowledges a scholarship 567 SFRH/BSAB/ 127907/2016 from the Foundation for Science and Technology (Portugal).

\section{References}

Adriano, D. C. (2001). Trace elements in terrestrial environments. Biogeochemistry bioavailability and risk of metals. New York: Springer.

Ahmed, H., Young, S., \& Shaw, G. (2012). Solubility and mobility of thorium and uranium in soils: The effect of soil properties on Th and $\mathrm{U}$ concentrations in soil solution. In EGU General Assembly (Vol. 14) EGU 2012-2994. 
Aitchison, J. (1986). The statistical analysis of compositional data. ournal of the Royal Statistical Society, 44, 139-177.

Albuquerque, M. T. D., Gerassis, S., Sierra, C., Taboada, J., Martín, J. E., Antunes, I. M. H. R., et al. (2017). Developing a new Bayesian Risk Index for risk evaluation of soil contamination. Science of the Total Environment, 603-604, 167-177.

Alloway, B. J. (1995). Heavy metals in soils (2nd ed., p. 368). London: Blackie Academic \& Professional.

Antunes, I. M. H. R., Neiva, A. M. R., Albuquerque, M. T. D., Carvalho, P. C. S., Santos, A. C. T., \& Cunha, P. P. (2018). Potential toxic elements in stream sediments, soils and waters in an abandoned radium mine (Central Portugal). Environmental Geochemistry and Health, 40, 521-524.

Boente, C., Albuquerque, M. T. D., Fernández-Braña, A., Gerassis, S., Sierra, C., \& Gallego, J. R. (2018a). Combining raw and compositional 1 data to determine the spatial patterns of Potentially Toxic Elements in soils. Science of the Total Environment, 631-632, 1117-1126.

Boente, C., Sierra, C., Martínez-Blanco, D., Menéndez-Aguado, J. M., \& Gallego, J. R. (2018b). Nanoscale zero-valent iron-assisted soil washing for the removal of potentially toxic elements. Journal of Hazardous Materials, 350, 55-65.

Bone, S. E., James, J. D., Cliff, J. J., \& Bargar, J. R. (2017). Uranium(IV) adsorption by natural organic matter in anoxic sediments. PNAS, 114, 711-716.

British standard (BS) 7755. (1995a). Soil quality, part 3. Chemical methods, section 3.2. Determination of $\mathrm{pH}$. ISO 10390, 1995.

British standard (BS) 7755. (1995b). Soil quality, part 3. Chemical methods, section 3.4. Determination of specific electrical conductivity. ISO 11265, 1994.

Buccianti, A., \& Grunsky, E. (2014). Compositional data analysis in geochemistry: Are we sure to see what really occurs during natural processes? Journal of Geochemical Exploration, 141, 1-5.

Campbell, G. P., Curran, J. M., Miskelly, G. M., Coulson, S., Yaxley, G. M., Grunsky, E. C., et al. (2009). Compositional data analysis for elemental data in forensic science. Forensic Science International, 188, 81-90.

Canadian soil guidelines (2017). Canadian soil quality guidelines for the protection of environmental and human health. Summary tables (pp. 1-6).

Chernov, V. A. (1947). The nature of soil acidity (p. 169). Madison: Soil Science Society of America.

Cumberland, S. A., Douglas, G., Grice, K., \& Moreau, J. W. (2016). Uranium mobility in organic matter-rich sediments: A review of geological and geochemical processes. Earth-Science Reviews, 159, 160-185.

Decreto Ministerial. (1999). Approvazione dei metodi ufficiali di andisi chimica del suolo. 50 Gaz. Uff.

de Souza, J. J. L. L., Abrahão, W. A. P., de Mello, J. W. V., da Silva, J., da Costa, L. M., \& de Oliveira, T. S. (2015). Geochemistry and spatial variability of meta (loid) concentrations in soils of the state of Minas Gerais, Brazil. Science of the Total Environment, 505, 338-349.

Duff, M., Coughliny, J. U., \& Hunter, D. B. (2002). Uranium coprecipitation with iron oxide minerals. Geochimica et Cosmochimica Acta, 66, 3533-3547.
Farias, P., Gallastegui, G., Lodeiro, F. G., Marquinez, J., Parra, L. L. M., Catalán, J. R. M., et al. (1987). Appontaciones al conocimiento de la lito-estratigrafia y estrutura de Galicia Central. IX Reunion de Geologia do Oeste Peninsular. Publ. Mus. Mineral., Geol. Fac. Ciências, Univ. Porto, Program Abstr. (Vol. 1, pp. 411-431).

Filzmoser, P., Hron, K., \& Reimann, C. (2009). Univariate statistical analysis of environmental (compositional) data: Problems and possibilities. Science of the Total Environment, 407, 6100-6108.

Fortes, C., Filipe, A. \& Parra, A. (2001). SIORMIMP: 1510 U. Mortórios.

Fu, H., Zhang, H., Sui, Y., Hu, N., Ding, D., Ye, Y., et al. (2018). Transformation of uranium species in soil during redox oscillations. Chemosphere, 208, 846-853.

Goldberg, S. (2002). Competitive adsorption of arsenate and arsenite on oxides and clay minerals. Soil Science Society of America Journal, 66, 413-421.

González-Fernández, B., Rodríguez-Valdés, E., Boente, C., Menéndez-Casares, E., Fernández-Braña, A., \& Gallego, J. R. (2018). Long-term ongoing impact of arsenic contamination on the environmental compartments of a former mining-metallurgy area. Science of the Total Environment, 610-611, 820-830.

Goovaerts, P. (1997). Geostatistics for natural resources evaluation. New York, Oxford: University Press.

Greenacre, M., \& Lewi, P. (2009). Distributional equivalence and subcompositional coherence in the analysis of compositional data, contingency tables and ratio-scale measurements. Journal of Classification, 26, 29-54.

Gringarten, E., \& Deutsch, C. V. (2001). Teacher's aide variogram interpretation and modeling. Mathematical Geology, 33, 507-534.

Gruan, G., Dia, A., Olivie-Lauquet, G., \& Serrat, E. (2000). The effects of organic matter and seasonal redox dynamics on chemical weathering: Constraints from natural wetland studies. Journal of Conference Abstracts, 5, 463.

IGE - Instituto Geofísico do Exército. (1994). Carta militar de Portugal, escala 1:25000, continente, série M888, Folha 160, Torre do Terranho (Trancoso), $2^{\mathrm{a}}$ edição.

Inácio, M., Pereira, V., \& Pinto, M. (2008). The soil geochemical atlas of Portugal: Overview and applications. Journal of Geochemical Exploration, 98, 22-33.

Isaaks, E. H., \& Srivastava, R. M. (1989). An introduction to applied geostatistics (pp. 278-322). New York, Oxford: University Press.

JEN - Junta de Energia Nuclear. (1959). Relatório de execução do plano de sanjas $\mathrm{n}^{\circ} 247$ (Mortórios). Informação $\mathrm{n}^{\circ}$ $135 / 49$.

Journel, A. G., \& Huijbregts, C. J. (1978). Mining geostatistics. San Diego: Academic Press.

Lahr, J., \& Kooistra, L. (2010). Environmental risk mapping of pollutants: State of the art and communication aspects. Science of the Total Environment, 408, 3899-3907.

Li, P., Lin, C., Cheng, H., Duan, X., \& Lei, K. (2015). Contamination and health risks of soil heavy metals around a lead/zinc smelter in south western China. Ecotoxicology and Environmental Safety, 113, 391-399.

Lind, O. C., Stegnar, P., Tolongutov, B., Rosseland, B. O., Strømman, G., Uralbekov, B., et al. (2013). Environmental impact assessment of radionuclide and metal 
contamination at the former U site at Kadji Sai, Kyrgyzstan. Journal of Environmental Radioactivity, 123, 37-49.

Loska, K., Wiechula, D., \& Korus, I. (2004). Metal contamination of farming soils affected by industry. Environment International, 30, 159-165.

Madruga, M. J., Carvalho, F., Reis, M., Alves, J., Corisco, J., Trindade, R., et al. (2010). Programas de Monitorização Radiológica Ambiental (Ano 2009) Relatório UPSR-A, no 37/10. Instituto Tecnológico e Nuclear, Unidade de Protecção e Segurança Radiológica.

Matheron, G. (1963). Principles of geostatistics. Economic Geology, 58, 1246-1266.

Négrel, P., De Vivo, B., Reimann, C., Ladenberger, A., Cicchella, D., Albanese, S., et al. (2018). U-Th signatures of agricultural soil at the European continental scale (GEMAS): Distribution, weathering patterns and processes controlling their concentrations. Science of The Total Environment., 622, 1277-1293.

Neiva, A. M. R., Antunes, I. M. H. R., Carvalho, P. C. S., \& Santos, A. C. T. (2016). Uranium and arsenic contamination in the former Mondego Sul uranium mine area, Central Portugal. Journal of Geochemical Exploration, 162, 1-15.

Neiva, A. M. R., Carvalho, P. C. S., Antunes, I. M. H. R., Santos, A. C. T., \& Cabral-Pinto, M. M. S. (2015). Spatial and temporal variability of surface water and groundwater before and after the remediation of a Portuguese uranium mine area. Chemie der Erde, 75, 345-356.

Nye, P., Craig, D., Colemnan, N. T., \& Ragland, J. L. (1961). For exchange equilibria involving aluminum. Soil Science Society of America Journal Proceedings, 25, 14-17.

Oliveira, J. T., Pereira, E., Ramalho, M., Antunes, M. T. \& Monteiro, J. H. (1992). Carta Geológica de Portugal à escala 1:500 000, Folha Norte, $5^{\mathrm{a}}$ edição. Serv. Geol. Portugal, Lisboa.

Pawlowsky-Glahn, V., \& Buccianti, A. (2011). Compositional data analysis: Theory and applications. New York: Wiley.

Pawlowsky-Glahn, V., \& Egozcue, J. J. (2006). Compositional data and their analysis: An introduction. Geological Society, London, Special Publications, 264, 1-10.

Quintela, A. (2015). Remediação ambiental da antiga área mineira de Mortórios. Seminário de gestão, projeto, construção e encerramento de instalações de resíduos mineiros. Ordem dos Engenheiros, Lisboa.

Reimann, C., Filzmoser, P., Fabian, K., Hron, K., Birke, M., Demetriades, A., et al. (2012). The concept of compositional data analysis in practice-Total major element concentrations in agricultural and grazing land soils of Europe. Science of the Total Environment, 426, 196-210.

Salminen, R., Batista, M. J., Bidovec, M., Demetriades, A., De Vivo, B., De Vos, W., Duris, M., et al. (2005). FOREGSGeochemical atlas of Europe. Part 1: Background information, methodology and maps. Espoo, Geological Survey of Finland, 526 pages, 36 figures, 362 maps.

Santos-Francès, F., Pacheco, E. G., Martínez-Graña, A., Rojo, P. A., Zarza, C. A., \& Sánchez, A. G. (2018). Concentration of uranium in the soils of the west of Spain. Environmental Pollution, 236, 1-11.

Selvakumar, R., Ramadoss, G., Menon, M. P., Rajendran, K., Thavamani, P., Naidu, R., et al. (2018). Challenges and complexities in remediation of uranium contaminated soils: A review. Journal of Environmental Radioactivity, 192, 592-603. https://doi.org/10.1016/j.jenvrad.2018.02. 018.

Swedish guidelines for soils. (2009). Swedish environmental protection agency generic guideline values for soils. Annexed to EQS and guideline values for contaminated sites. Report 2017. INSURE Innovative Sustainable Remediation. European Union. Central Baltic.

Tabatabai, M. A. (1996). Soil organic matter testing: An overview (pp. 1-10). In F. Magdoff et al. (Eds.) Soil organic matter: Analysis and interpretation. SSSA Spec. Pub. 46. Madison, WI: American Society of Agronomy.

Taboada, T., Cortizas, A. M., Carcía, C., \& García-Rodeja, E. (2006). Uranium and thorium in weathering and pedogenetic profiles developed on granitic rocks from NW Spain. Science of the Total Environment, 356, 192.

Thomas, G. W. (1982). Exchangeable cations. Methods of soil analysis part 2, Chemical and microbiological properties (2nd ed.). In A. L. Page et al. (Eds.) Agronomy (Vol. 9, pp. 154-157). American Society of Agronomy, Soil Science Society of America, Madison.

Tserenpil, Sh, Maslov, O. D., Norov, N., Liu, Q. C., Filipov, M. F., Benny, K. G., et al. (2013). Chemical and mineralogical composition of the Mongolian rural soils and their uranium sorption behavior. Journal of Environmental Radioactivity, $118,105-112$.

User manual. (2001). Jobin Yvon ICP spectrometers, version 3.0. Reference: 31088486, January 2001 (pp. 20-23).

Publisher's Note Springer Nature remains neutral with regard to jurisdictional claims in published maps and institutional affiliations. 